\title{
Clinical, ultrasound and chromosome findings of testicles in a French bulldog (Canis Iupus familiaris)
} with azoospermia

\author{
Salome Agudelo-Yepes, Yundrum Militza Rivillas, Diego Fernando \\ Carrillo-González and Walter D. Cardona-Maya*
}

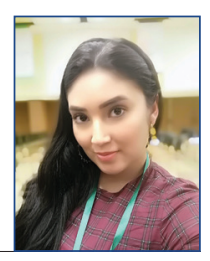

\begin{abstract}
This case report describes azoospermia in a French bulldog. The dog, with historical evidence of unsuccessful insemination after both artificial insemination and natural breeding, presented with physiological parameters (testosterone levels and karyotype) within normal ranges. Scrotal palpation and ultrasound of both testicles indicated aplasia of the epididymis and vas deferens.
\end{abstract}

Two seminal samples were examined and no sperm cells were found. In conclusion, before starting an assisted reproduction procedure, it is necessary to perform sperm analysis to determine the reproductive capacity of the dog intended as a stud dog.

Key words: dog; infertility; reproduction; sperm; breeders

\section{Introduction}

The stud dog is half the equation when evaluating potential causes of infertility in canine breeding (Kolster, 2018). Therefore, the assessment of semen parameters, such as volume, concentration, motility, and sperm

morphology, must be included in conventional reproductive analysis when selecting a stud dog (Freshman, 2002; Kolster, 2018). Before obtaining a semen sample, it is also necessary to perform an anatomical examination to determine the

\footnotetext{
Salome AGUDELO-YEPES, Microbiol. Student, Reproduction Group, Department of Microbiology and Parasitology, Medical School, University of Antioquia, Antioquia, Colombia; Yundrum Militza RIVILLAS, Biological Engineering, Animal Biotechnology Group, National University of Colombia, Science Faculty, Medellin, Colombia; Diego Fernando CARRILLO-GONZÁLEZ, MVZ, MSc, PhD, One Health and Veterinary Innovative Research \& Development Group, School of Veterinary Medicine, University of Antioquia, Medellin, Colombia, Faculty of Agricultural Sciences, School of Zootechnics, Universidad de Sucre, Sincelejo, Colombia; Walter D. CARDONA-MAYA*, Bact., MSc, PhD, (Corresponding author: e-mail: wdario.cardona@udea.edu.co), Reproduction Group, Department of Microbiology and Parasitology, Medical School, University of Antioquia, Antioquia, Colombia
} 
level of development of the testes, penis, and spermatic ducts.

Occasionally, breeders do not consider the anatomic development of their stud dogs, and hence initiate the sperm collection protocol to determine the reproductive capacity of male dogs without first collecting any anatomical knowledge. Thus, there is a risk of obtaining seminal samples without the presence of sperm, i.e. azoospermic ejaculate. Azoospermia is defined as the total absence of spermatozoa in two ejaculated semen samples with an interval of 2 to 3 months. The etiology might be related to pre-testicular, testicular or post-testicular causes (Olson et al., 1992; Metcalfe et al., 1999; Gradil et al., 2006). Hypogonadotropic hypogonadism is the most common cause of pre-testicular azoospermia, and is induced by endocrine disorders such as hypothyroidism or Cushing's syndrome. Other common causes are increased testicular temperature, scrotal hernia or testicular neoplasm. Testicular azoospermia can be caused by congenital (genetic abnormalities) or acquired (testicular torsion, trauma or varicocele) defects (Olson et al., 1992; Metcalfe et al., 1999). Finally, post-testicular causes of azoospermia are conditions that obstruct the release of semen during ejaculation, including sperm granuloma, segmental epididymal aplasia and spermatocele (Olson et al., 1992; Metcalfe et al., 1999).

Dogs with azoospermia show an absence of sperm cells in ejaculate, and this alteration might have an incidence of up to $35 \%$. Azoospermia is usually classified as either obstructive or nonobstructive, where the obstructive type is less common (Huang et al., 2018).

Clinically, it is important to identify a dog that does not ejaculate the spermrich fraction (only pre-sperm prostate fluid) due to anxiety or inappropriate sexual stimulation, in order to avoid a misleading diagnosis of azoospermia (Memon,
2007). Paradoxically, azoospermia has been reported in both purebred and crossbreed dogs. It is even common to find an azoospermic dog that has previously bred a litter, and then experienced a process impairing the ejaculation process (Memon, 2007).

Differential diagnosis must be made of chromosomal defects, testicular hypoplasia, Sertoli cells syndrome, bilateral cryptorchidism, hypopituitarism, or Cushing syndrome due to extensive steroid administration, bilateral sperm granuloma, antineoplastic therapy, collection in prepubertal dogs, pain, fear or inadequate excitement (Memon, 2007). Diagnostic tests may include karyotype, complete seminal evaluation, stimulation test with luteinizing hormone and follicle-stimulating hormone, and measurement of testosterone, prolactin, and total oestrogen concentrations (Lopate, 2012). This case report describes azoospermia of a French bulldog used by its owner as a stud dog.

\section{Case report}

A 30-month-old male dog of the French bulldog breed, with a recurring history of failing to impregnate females after natural breeding or artificial insemination was received to determine his reproductive capacity.

The Institutional Board on Animal Subject Experimentation from the University of Antioquia approved this study. A complete general and andrological medical examination was performed on the dog. During the general clinical examination, its behaviour was normal (Fig. 1A), and it exhibited typical male characteristics, e.g. urination (marking territory), the search for females, and armed and protrusion of the penis (Fig. 1B). In addition, the general conditions of the dog and its physiological parameters (heart and respiratory rate, pulse, and 
Clinical, ultrasound and chromosome findings of testicles in a French bulldog (Canis lupus familiaris) with azoospermia Klinički, ultrazvučni i kromosomski nalazi testisa u francuskog buldoga (Canis lupus familiaris) s azoospermijom
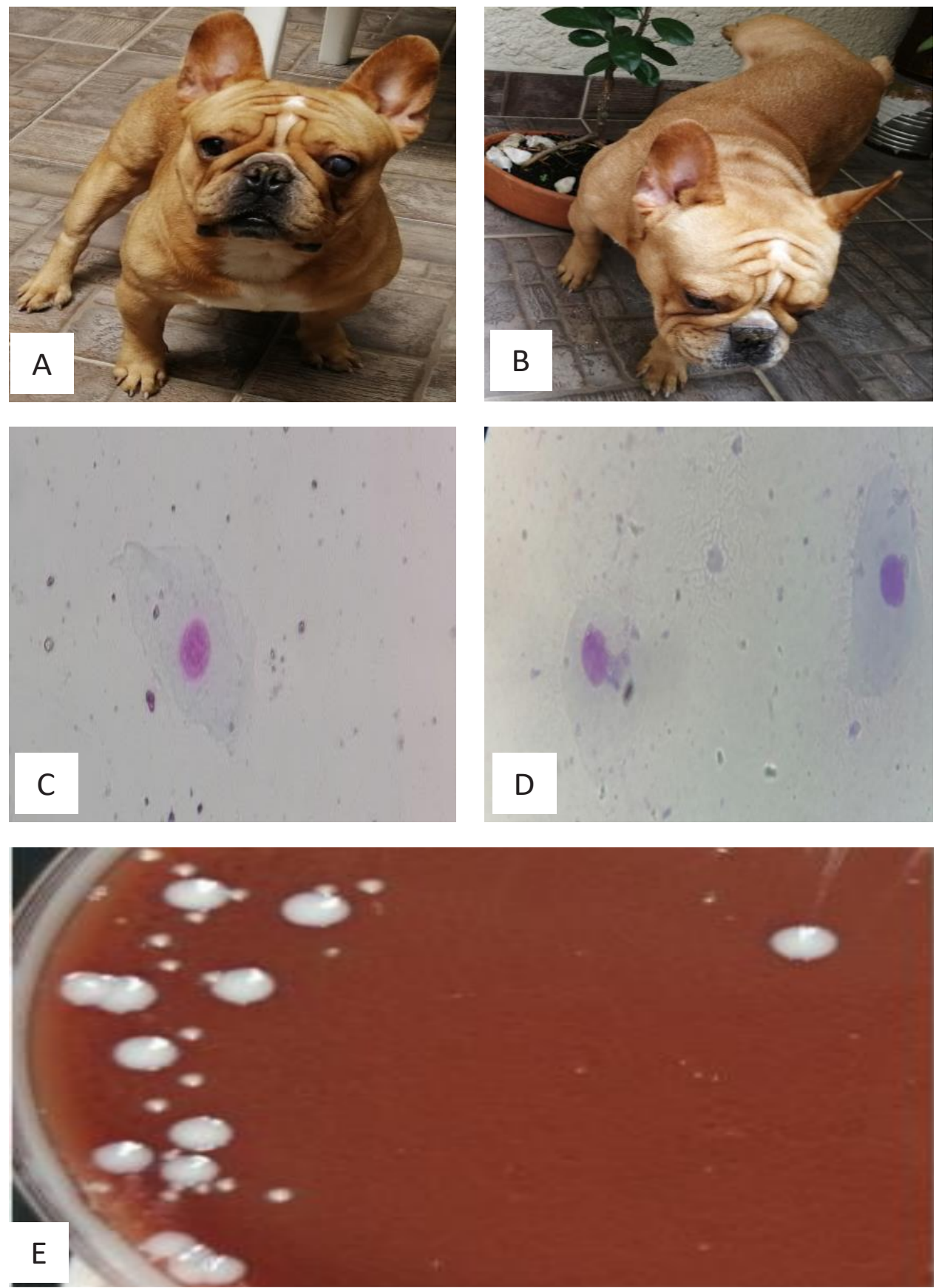

Figure 1. A. French bulldog with supposed normal appearance. B. Typical male behaviour when lifting the leg for urination. C-D. Extended of the ejaculate stained with Giemsa, only cells of the epithelium of scaling are observed, with a complete absence of sperm, 40x. E. Colonies of Staphylococcus aureus (large) and Staphylococcus coagulase negative (small) in chocolate agar obtained by seeding by confluence. 

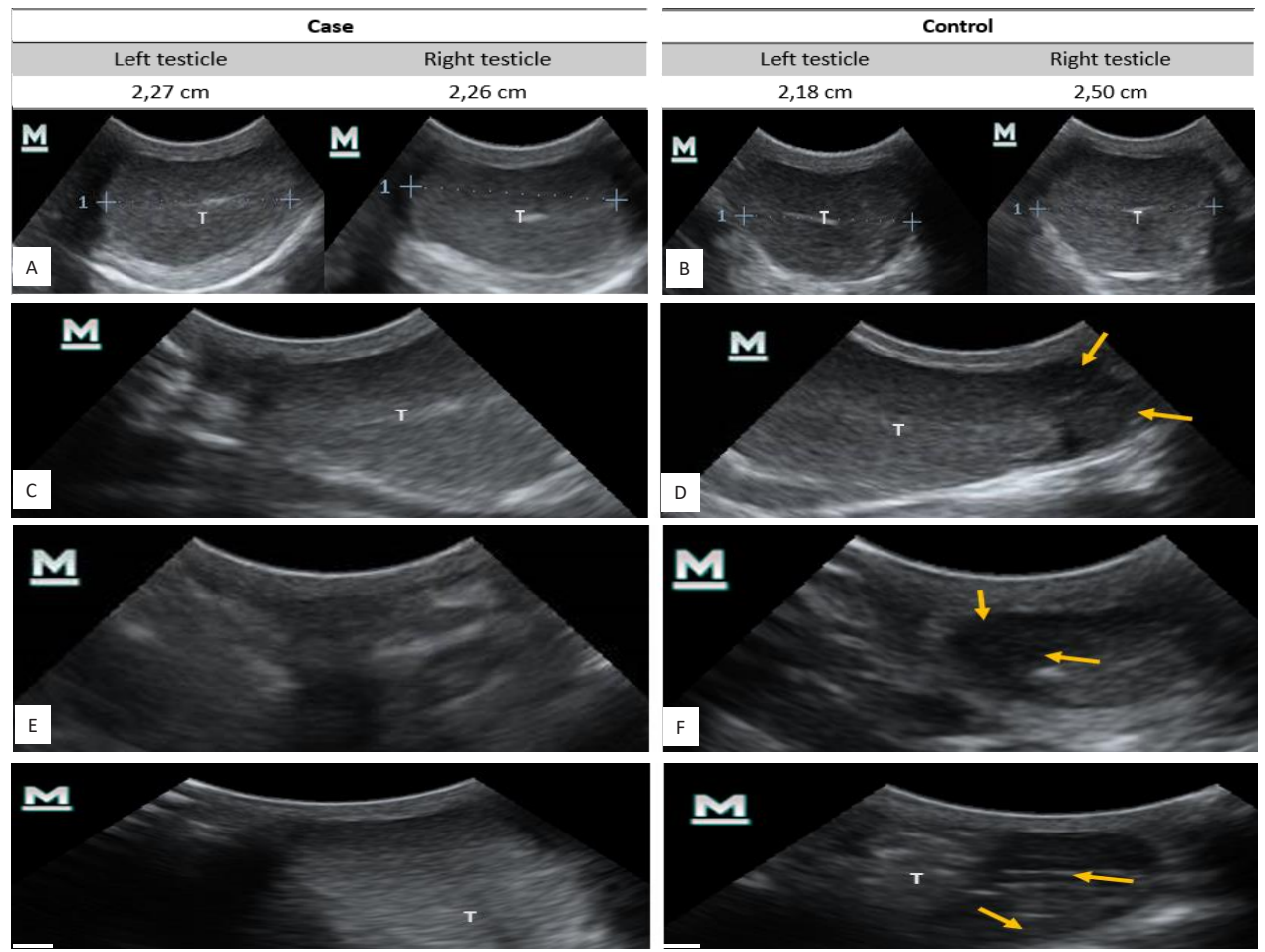

Figure 2. A-B Ultrasound of the cross section of the testis and measurement of testicular diameter. A. The left and right testicles of the male subject are of uniform echogenicity, with a well-defined testicular mediastinum. Additionally, they have testicular symmetry in diameter. B. Control canine testicles, with normal echogenicity and testicular symmetry. C-D. Sagittal ultrasound of the testicle. C. In the sagittal section, the well-developed testis (T) is observed, without the presence of fibrous areas or ischemia, however, in the caudal portion, it is not possible to differentiate the tail of the epididymis. D. Testicle (T) of normal morphology. The tail of the epididymis (yellow arrows) is observed in the caudal portion. E-F. Ultrasound of the cross-sectional flow to the testis. E. The presence of the epididymis is not observed in the area immediately caudal to the testis. F. In the control male, the tail of the epididymis (yellow arrows) is seen as an anechogenic region caudal to the testis, demonstrating the normal morphology. G-H Ultrasound of sagittal caudal flow to the testis. G. The presence of the epididymis is not observed in the area immediately caudal to the testis (T). $\mathbf{H}$. In the control male, the tail of the epididymis (yellow arrows) is seen as an anechogenic region, located caudal to the testis (T), demonstrating the normal morphology.

temperature) were within normal levels, and the mucous membranes were moist, pink, and bright. During the andrological examination, the morphology of the penis was determined as normal. Finally, an abnormal morphology of the testicles was detected as the tail of the epididymis could not be palpated.

Subsequently, two semen samples were taken by gloved hand method with a two-month interval between samples, and each was assessed following recognized international standards (de los Rios et al., 2004; Cardona-Maya et al., 2008; World Health Organization, 2010). The findings for the two seminal evaluations were similar in terms of consistency of normal non-filament ejaculate, translucent yellowish-white in colour with a pH of 8 (Gradil et al., 2006). Light microscopy showed the complete absence of sperm, and desquamation cells were scarcely observed (Fig. 1CD). The results were the same in both 
evaluations; therefore, azoospermia was confirmed (Metcalfe et al., 1999).

Semen samples were subjected to bacteriological analyses and were seeded using a calibrated loop on chocolate agar. After 24 hours of incubation at $37^{\circ} \mathrm{C}$, 4200 colony forming units $(\mathrm{CFU} / \mathrm{mL})$ were counted (Puerta Suárez et al., 2015). Biochemical tests identified two types of colonies: Staphylococcus aureus and Staphylococcus coagulase negative (Fig. 1E).

To confirm the semen analysis findings in the testicular palpation, testicular ultrasound was performed with the Mindray DP30 VET device with a linear probe, in transverse section, sagittal section, caudal transverse section and caudal sagittal section, and testicular diameter was measured for both testicles. Ultrasound showed that testicular diameter was within the normal range (Fig. 2A-B), testicular tissue was healthy and without fibrosis. However, it was not possible to identify the epididymis tail immediately caudal to the testicle on both sides (Fig. 2C-H). Another dog with similar characteristics was used as a control during the ultrasound test. A blood sample was collected to assess total testosterone levels, using the enzyme immunoassay technique (ELISA) with the Canine free testosterone kit (fT ELISA Kit, MyoBioSource). The estimated total testosterone level (3.89 ng/mL) showed the basic androgenic value in males (range 3.0-10.0 ng/mL) (DePalatis et al., 1978; Gradil et al., 2006; Hornakova et al., 2019)

In order to rule out chromosomal etiology, a karyotype test was performed. The cultures for obtaining the chromosome spreads were taken following the method described by Moorhead et al. (1960), using phytohemagglutinin (1.5\% $\mathrm{v} / \mathrm{v}$, SIGMA). R bands were obtained by incorporating 5-bromo-2'-deoxyu-
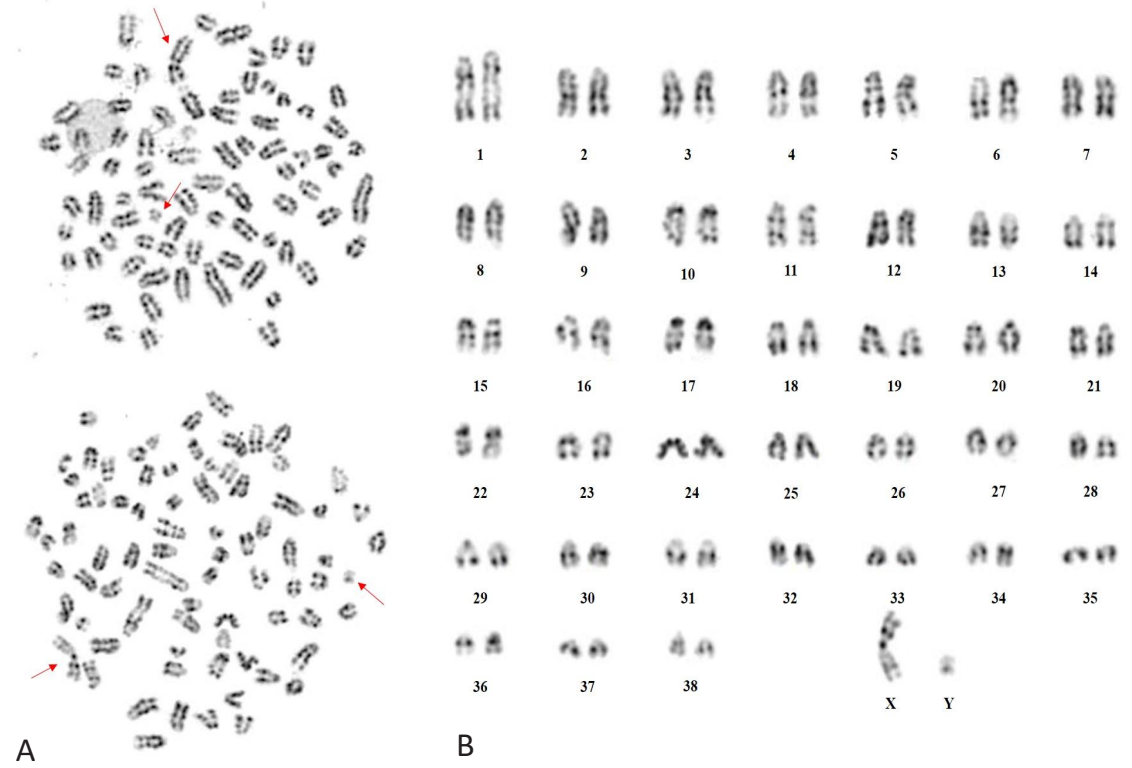

Figure 3. A. Extended chromosomal 78, XY, with RBG banding pattern, with 38 autosomal acrocentric pairs and a sexual chromosomal pair $X$ (metacentric) and $Y$ (metacentric) indicated by arrow. B. Karyotype of the case study: 78, XY, with RBG banding pattern, with 38 autosomal acrocentric pairs and one sex chromosomal pair $X$ (metacentric) and $Y$ (metacentric). 
ridine (BrdU, RBG bands) and metaphase chromosomes by adding Colcemid (SIGMA). Subsequently, the samples were dripped on plates to stain and reveal the RBG bands (Camargo and Cervenka, 1982), with the respective modifications (López and Márquez, 2002). A total of 60 metaphases were analysed (100X magnification) and the images were captured with a Nikon camera and analysed with GenAsis software. All mitoses analysed had a chromosomal number $2 \mathrm{n}=78$, i.e. 38 autosomal acrocentric chromosomal pairs and a metacentric sexual chromosomal pair, which concurs with a previous study for this breed (Reimann et al., 1996). No numerical or structural alterations such as translocations, investments or major rearrangements were observed. It should be mentioned that all the metaphases evaluated had a 78, XY chromosomal constitution that indicates that the sample belongs to a male (Fig. 3). On the other hand, no alterations in the morphology or in the banding pattern of the sex chromosomes were found. With the number of metaphases analysed, a mosaicism of $4.6 \%$ with a certainty of $95 \%$ is ruled out, meaning that this individual has a cellular mixture type $X X$ / $\mathrm{XY}$ or XY / X0 lower than $4.6 \%$, it is possibly undetected with this study. These results are only related to the tested sample. Figure 3A shows two extended chromosomes: the sex chromosomes are indicated with an arrow, while Figure 3B shows the karyotype made from one of the evaluated metaphases.

\section{Discussion}

Based on the seminal evaluation, testosterone levels, karyotype, and the ultrasound, the diagnosis of aplasia of the vas deferens and epididymis was confirmed. Thus, castration of the male was recommended, eliminating it from use as a stud dog. The owner did not approve the procedure, and preferred to keep the patient as a companion pet in his home.

Recently, a retrospective study (Tesi et al., 2018) evaluated 251 semen samples from 140 dogs and reported that $9.6 \%$ (24) of the animals presented azoospermia. An azoospermic dog should always receive careful palpation and ultrasound examination of the epididymis and spermatic cords to detect possible abnormalities of the reproductive tract (Gradil et al., 2006). This report confirms the importance of determining seminal quality in animals, especially those used for reproductive purposes. We have described how the azoospermia of this dog could be classified as being of testicular origin, likely due to an epididymis malformation or atrophy. The fundamental role of the epididymis on sperm has been widely documented, as during transit from the head of the epididymis to the tail, sperm undergo functional and structural changes that result in its completes maturation, allowing recognition of and interaction with oocytes (Cooper, 2011; Varesi et al., 2013). Furthermore, the epididymis has numerous interrelated functions, including absorption and secretion activities that affect the luminal environment and the cell membrane (Contri et al., 2012). Ultimately, another important role of the epididymis has to do with the recognition and elimination of abnormal sperm by means of an ubiquitin-dependent sperm quality control mechanism present in the mammalian epididymis (Sutovsky et al., 2001; McIntyre et al., 2002).

Based on the presented results, we conclude that it is essential to perform a complete reproductive evaluation of male dogs considered for reproductive purposes. The epididymis should be examined for abnormalities in shape, size or consistency, such as a sperm granuloma. If during soft palpation a 
pain reflex is aroused, acute epididymitis should be considered. This assessment should also include the clinical and reproductive history, an andrological and general physical examination, and semen collection for sperm analysis.

Additionally, when necessary, bacteriological culture of the semen should be performed. On the other hand, if the animal will be used for reproduction purposes, animals must be free of Brucella canis. Testicular and prostate ultrasound may be useful for diagnosis, and the determination of serum testosterone or other endocrine sera levels may also be useful (Gradil et al., 2006).

In conclusion, before starting an assisted reproduction procedure, it is necessary to perform several tests to demonstrate the reproductive capacity of the dog intended as a stud dog. Only a complete reproductive evaluation will ensure that losses of time and money in production models for pet animals are avoided.

\section{References}

1. CAMARGO, M. and J. CERVENKA (1982): Patterns of DNA replication of human chromosomes. II. Replication map and replication model. Am. J. Hum. Genet. 34, 757-780.

2. CARDONA-MAYA, W., J. BERDUGO and A. CADAVID (2008): Comparing the sperm concentration determined by the makler and the neubauer chambers. Actas Urol. Esp. 32, 443-445.

3. CONTRI, A., A. GLORIA, D. ROBBE, I. De AMICIS and A. Carluccio (2012): Characteristics of donkey spermatozoa along the length of the epididymis. Theriogenology 77, 166-173.

4. COOPER, T. G. (2011): The epididymis, cytoplasmic droplets and male fertility. Asian J. Androl. 13, 130-138.

5. de los RIOS, J., W. D. CARDONA, J. A. BERDUGO, C. CORREA, A. ARENAS, M. OLIVERA-ANGEL, R. B. PENA and A. P. CADAVID (2004): [Sperm parameters in 113 subjects after recent fatherhood did not correlate with WHO standards]. Arch. Esp. Urol. 57, 147-152.

6. DePALATIS, L., J. MOORE and R. E. FALVO (1978): Plasma concentrations of testosterone and LH in the male dog. J. Reprod. Fertil. 52, 201-207.

7. FRESHMAN, J. L. (2002): Semen collection and evaluation. Clin. Tech. Small Anim. Pract. 17, 104-107.
8. GRADIL, C. M., A. YEAGER and P. W. CONCANNON (2006): Evaluación de los problemas reproductivos del macho canino. In: E. G. Concannon, P. W., Verstegen III J. and LindeForsberg C., eds., Recent Advances in Small Animal Reproduction (International Veterinary Information Service, Ithaca NY).

9. HORNAKOVA, L., J. DIANOVSKY, B HOLECKOVA and K. SIVIKOVA (2019): A comprehensive study of disorder of sex development in Staffordshire bull terrier dog. Reprod. Domest. Anim. 54, 928-935.

10. HUANG, I. S., W. J. HUANG and A. T. LIN (2018): Distinguishing non-obstructive azoospermia from obstructive azoospermia in Taiwanese patients by hormone profile and testis size. J. Chin. Med. Assoc. 81, 531-535.

11. KOLSTER, K. A. (2018): Evaluation of Canine Sperm and Management of Semen Disorders. Vet Clin. North Am. Small Anim. Pract. 48, 533-545.

12. LOPATE, C. (2012): The problem stud dog. Vet. Clin. North Am. Small Anim. Pract. 42, 469-488.

13. LÓPEZ, J. B. and M. E. MÁRQUEZ (2002): Modelo experimental para el estudio cromosómico en células de mamíferos. (Universidad Nacional de Colombia, Medellín).

14. McINTYRE, B. S., N. J. BARLOW and P. M. FOSTER (2002): Male rats exposed to linuron in utero exhibit permanent changes in anogenital distance, nipple retention, and epididymal malformations that result in subsequent testicular atrophy. Toxicol. Sci., 65, 62-70.

15. MEMON, M. A. (2007): Common causes of male dog infertility. Theriogenology 68, 322-328.

16. METCALFE, S. S., I. M. GUNN and K. A. CHAMPNESS (1999): Azoospermia in two Labrador retrievers. Aust. Vet. J. 77, 570-573.

17. MOORHEAD, P. S., P. C. NOWELL, W. J. MELLMAN, D. M. BATTIPS and D. A HUNGERFORD (1960): Chromosome preparations of leukocytes cultured from human peripheral blood. Exp. Cell Res. 20, 613-616.

18. OLSON, P. N., P. SCHULTHEISS and H. B. SEIM (1992): Clinical and laboratory findings associated with actual or suspected azoospermia in dogs: 18 cases (1979-1990). J. Am. Vet. Med. Assoc. 201, 478-482.

19. PUERTA SUÁREZ, J., A. VILLEGAS CASTAÑO, G. J. SERNA QUINTANA, A. MARTÍNEZ, J. ROMERO PALACIO, M. GIRALDO, A. CADAVID and W. CARDONA MAYA (2015): Espermocultivo: crecimiento bacteriano del eyaculado y su relación con los parámetros seminales. Revista Cubana de Obstetrícia y Ginecología 80, 33-40.

20. REIMANN, N., S. BARTNITZKE, J. BULLERDIEK, U. SCHMITZ, P. ROGALLA, I. NOLTE and M RONNE (1996): An extended nomenclature of the canine karyotype. Cytogenet. Cell Genet. 73, 140144.

21. SUTOVSKY, P., R. MORENO, J. RAMALHOSANTOS, T. DOMINKO, W. E. THOMPSON and G. SCHATTEN (2001): A putative, ubiquitin- 
dependent mechanism for the recognition and elimination of defective spermatozoa in the mammalian epididymis. J. Cell Sci. 114, 1665-1675.

22. TESI, M., C. SABATINI, I. VANNOZZI, G. DI PETTA, D. PANZANI, F. CAMILLO and A. ROTA (2018): Variables affecting semen quality and its relation to fertility in the dog: A retrospective study. Theriogenology 118, 34-39.
23. VARESI, S., V. VERNOCCHI, M. FAUSTINI and G. C. LUVONI (2013): Morphological and acrosomal changes of canine spermatozoa during epididymal transit. Acta Vet. Scand. 55, 17.

24. World Health Organization (2010): World Health Organization laboratory manual for the examination and processing of human semen. World Health Organization: Geneva, Swtizerland, 287.

\section{Klinički, ultrazvučni i kromosomski nalazi testisa u francuskog buldoga (Canis lupus familiaris) s azoospermijom}

Salome AGUDELO-YEPES, student mikrobiologije, Grupa za reprodukciju, Zavod za mikrobiologiju i parazitologiju, Medicinski fakultet, Univerzitet u Antioquiai, Antioquia, Kolumbija; Yundrum Militza RIVILLAS, Biološki inženjering, Grupa animalne biotehnologije, Nacionalni univerzitet Kolumbije, Fakultet znanosti, Medellin, Kolumbija; dr. sc. Diego Fernando CARRILLO-GONZÁLEZ, MVZ, MSc, Jedno zdravlje i veterinarsko inovativno istraživanje \& grupa za razvoj, Veterinarski fakultet, Univerzitet u Antioquiai, Medellin, Kolumbija, Fakultet poljoprivrednih znanosti, Zootehnički fakultet, Univerzitet de Sucre, Sincelejo, Kolumbija; dr. sc. Walter D. CARDONA-MAYA, Grupa za reprodukciju, Zavod za mikrobiologiju i parazitologiju, Medicinski fakultet, Univerzitet u Antioquiai, Antioquia, Kolumbija

Ovaj prikaz slučaja opisuje azoospermiju francuskog buldoga. Pas, s prethodnim anamnestičkim nalazima neuspješne oplodnje, kako nakon umjetnog osjemenjivanja, tako i parenja, imao je fiziološke parametre (razine testosterona i kariotip) unutar normalnih granica. Palpacija skrotuma i ultrazvuk oba testisa ukazali su na aplaziju nuzjaja i sjemenovoda. Ispitana su dva uzorka sjemena i nisu pronađeni spermiji. Zaključno, da bi se odredio reproduktivni kapacitet psa namijenjenog za rasplod, potrebno je prije početka postupka potpomognute oplodnje obaviti analizu sperme.

Ključne riječi: pas, neplodnost, reprodukcija, sperma, uzgajivači 